\title{
WILLIAM COOPER AND THE 1937 PETITION TO THE KING*
}

\author{
Andrew Markus
}

In the 1930s the perspective in which Europeans viewed Aborigines was in the process of change. For over half a century it had been widely accepted that the Aboriginal people would become extinct; now this belief was being undermined by the realisation that the part-Aboriginal population was increasing at a significant rate and by the growth in anthropological knowledge. Government policy which had been essentially negative in character, designed to minimise the nuisance value of Aborigines while making them available as a source of cheap labour, came under increasing attack from pressure groups agitating for a 'New Deal' premised on the assumption that Aborigines could 'advance' to European standards. By the second half of the decade a reappraisal of government policies was underway, brought to a head by an Australia wide conference of officials which met in Canberra in April 1937 and resolved, amongst other things, that the destiny of part-Aborigines 'lies in their ultimate absorption by the people of the Commonwealth'. ${ }^{1}$

Perhaps the most important of the pressure groups was the Association for the Protection of Native Races. Formed in 1911, it was Sydney based with an exclusively European membership, led for most of the 1930s by the Reverend William Morely and Professor A.P. Elkin. There were several other European run organisations concerned with the welfare of Aborigines in the southern mainland capitals: the Aboriginal Fellowship Group and the Aborigines' Uplift Society in Melbourne, the Aborigines' Friends' Association in Adelaide and the Australian Aborigines' Amelioration Association in Perth. The London based Anti-Slavery and Aborigines Protection Association and the Royal Anthropological Institute also took an active interest, as did a number of Australian organisations not exclusively concerned with Aborigines, especially church and women's groups (the Women's Christian Temperance Union, the Australian Federation of Women Voters) and communist controlled bodies such as the Unemployed Workers' Movement and International Labour Defence. ${ }^{2}$

Pressure group activity was not, however, the exclusive preserve of Europeans. At various times Aborigines made efforts to organise on their own behalf and the

Andrew Markus lectures at Riverina College of Advanced Education and is the author of several works on race relations in Australia. He is currently writing a book on Aborigines during the inter-war period.

* Mr Gillison Cooper and Mrs Sally Russell granted permission to reproduce letters written by their father. Queensland Newspapers Pty Ltd granted permission to reproduce a photograph of William Cooper. This article has benefited from the detailed comments of Diane Barwick. Research was undertaken with the support of the Australian Research Grants Scheme.

1 Aboriginal Welfare, 1937 ?.

2 The records of the Association for the Protection of Native Races are housed in the Archives, University of Sydney. Much of the correspondence between the Commonwealth and various organisations seems to have survived. See, for example, Australian Archives, CRS A1, 38/12974; CRS A431, 48/961; CRS A461, A300/1, Part II. See also Stanner and Barwick 1979. 
period 1935-40 is notable for the establishment and continued existence of the Aborigines' Progressive Association of New South Wales, formed in 1937 under the leadership of William Ferguson and Jack Patten, ${ }^{3}$ and the Melbourne based Australian Aborigines' League led by the elderly William Cooper, the subject of this article.

Cooper was born in Joti-jota land (in the vicinity of Echuca) about 1861 and worked as a shearer and labourer on pastoral properties for much of his life. One of the missionary Daniel Matthews' first pupils at Maloga, ${ }^{4}$ he attended adult literacy classes and emerged as a spokesman for Aborigines of central Victoria and western New South Wales. In 1933 when over seventy years of age he left Cumeroogunja reserve to become eligible for a pension and settled in Melbourne where he began a campaign to improve the condition of his people throughout the country. ${ }^{5}$ During 1933 and 1934 he seems to have acted in an individual capacity, then on behalf of the Real Australian Native Association and from mid 1935 the Australian Aborigines' League, an organisation in which full membership was restricted to persons 'possessing some degree of Aboriginal blood'. 6 Based on the 100 strong Melboume Aboriginal Community, many of whom were impoverished, the league's executive included in addition to Cooper his son Lynch, Douglas (later Sir Douglas) Nicholls, Margaret Tucker, Caleb Morgan, Mrs N. Clark, Mrs Lovett, and Misses Hylus Briggs, Julia Niven, A. Clark and M. Lovett. Two honorary members of European descent, A.P. Burdeu (president) and Helen Baillie (life member) were active in the league's work.7

3 Horner 1974.

4 Cato $1976: 69,114$.

5 Barwick 1981.

6 There is some doubt concerning the date of the league's formation. Cooper first refers to himself as Honorary Secretary of the A.A.L. in a handwritten letter dated 20 May 1935 (AA, CRS A1, 35/3951). The Association for the Protection of Native Races minute book for 17 March 1936 notes the receipt of a letter from A.P. Burdeu concerning the 'newly formed' league. The N.S.W. Aborigines Protection Board meeting of 4 March 1936 noted the receipt of similar correspondence from the league. The Register of Inwards Correspondence of the Victorian Board for the Protection of Aborigines discloses no correspondence with the league before 1936. In 1933 and 1934 Cooper wrote to the Board in an individual capacity. Compare Horner 1974:47.

7 Inspector R.S. Browne, 'Australian Aborigines' League', Commonwealth Investigation Branch report, - December 1937 (AA, CRS A431, 45/1591). Helen Baillie wrote in 'Some recollections of Mr A.P.A. Burdeu' (Typed circular, n.d., Association for the Protection of Native Races Records): 'I first made the acquaintance of Mr. Burdeu when I returned from a visit to England late in 1935. On my arrival I was met by Mr. William Cooper, founder and Hon. Secretary of the Australian Aborigines' League, the natives own organisation, who . . was a half-caste aboriginal who did valiant work on behalf of the Aborigines, who he always referred to as "My People". Mr. Cooper informed me that while I had been away he had found some one who was giving him great assistance in his work, and he shortly afterwards introduced me to Mr. Burdeu. Mr. Burdeu was at that time a salaried officer in the Railways Department at Spencer Street, and many were the visits paid to him during his lunch hour by Mr. Cooper and myself in order to consult him on some matter of aboriginal welfare. I was amazed how soon he had mastered the many complicated aspects of Aboriginal legislation. He also soon became the firm friend and councillor of the native...' 
The league's programme embodied nine major demands:

1. Control over Aborigines to be transferred from the states to the Commonwealth.

2. The implementation of a positive national policy of uplift.

3. Increased funding.

4. The ending of discrimination between Aborigines of full and part descent, and between Aborigines and Europeans.

5. The granting of full citizenship rights to 'civilized' Aborigines.

6. Recognition by the legal system of tribal laws in appropriate circumstances.

7. Full access to reserves and the granting of land.

8. The opening of educational opportunities to the highest level.

9. The granting of parliamentary representation on the New Zealand model. ${ }^{8}$

There is no record to explain the distinctive demand for parliamentary representation but in all likelihood the idea originated with Cooper whose correspondence indicates a keen interest in overseas developments. In New Zealand Maoris had been granted four parliamentary seats in 1867; at various times Maori members had held the balance of power in the New Zealand parliament, several having occupied the post of Minister of Native Affairs, starting with James Carroll in $1899 .^{\circ}$

Cooper and his fellow workers attempted to achieve their objectives through written appeals in the press and to politicians, public meetings and demonstrations. ${ }^{10}$ In January 1935 Cooper led a deputation to the Minister for the Interior and on 31 January 1938 was a member of a predominantly Aborigines' Progressive Association deputation which met with Prime Minister Lyons, Mrs Lyons and the then Minister for the Interior John (later Sir John) McEwen. ${ }^{11}$ Personal and kinship ties between members of the New South Wales and Victorian organisations provided the basis for co-operative action in 1937 and 1938, even though there was opposition to one of the league's primary objectives, the call for parliamentary representation: at this time Ferguson and Patten argued that the goal of Aborigines should be assimilation on the basis of full equality, not the winning of special privileges, although in 1940 Ferguson was to change his mind. ${ }^{12}$ Joint action reached a peak late in January 1938 when Cooper formed part of the deputation to the Prime Minister and a Melbourne delegation participated in the Sydney Day of Mourning demonstration. Coinciding with the sesquicentenary of European settlement the demonstration, an idea of Cooper's,

${ }^{8}$ See, for example, Australian Aborigines' League, 'Agenda of proposals . . . for the consideration of the Conference of Chief Protectors and others' (AA, CRS A461, A300/1, Part III).

9 Jackson and Wood 1964; Pocock 1965. James Carroll (knighted in 1911) was elected to Eastern Maori in 1887 and appointed a member of the Executive Council representing the Native Race in 1892 . From 1893 to 1919 he represented non-Maori electorates, occupied several ministeries and was acting prime minister on two occasions.

10 See, for example, Argus, 5 December 1934:10; 26 June 1936:5; 9 May 1938:9; 12 July 1938:13; 26 July 1938:16; Sun (Melbourne), 11 September 1936:6.

11 Herald (Melbourne); 23 January 1935; Argus, 24 January 1935:17; 1 February 1938:2; Abo Call, April 1938:1; AA, CRS A1, 35/3951.

12 Argus, 27 January 1938:2 (Ferguson); Abo Call, April 1938:2 (Patten); see also Patten and Ferguson 1938; Ferguson to His Exc. the Rt. Hon. Lord Gowrie, 30 August 1940 (AA, CRS A431, 49/1591). 


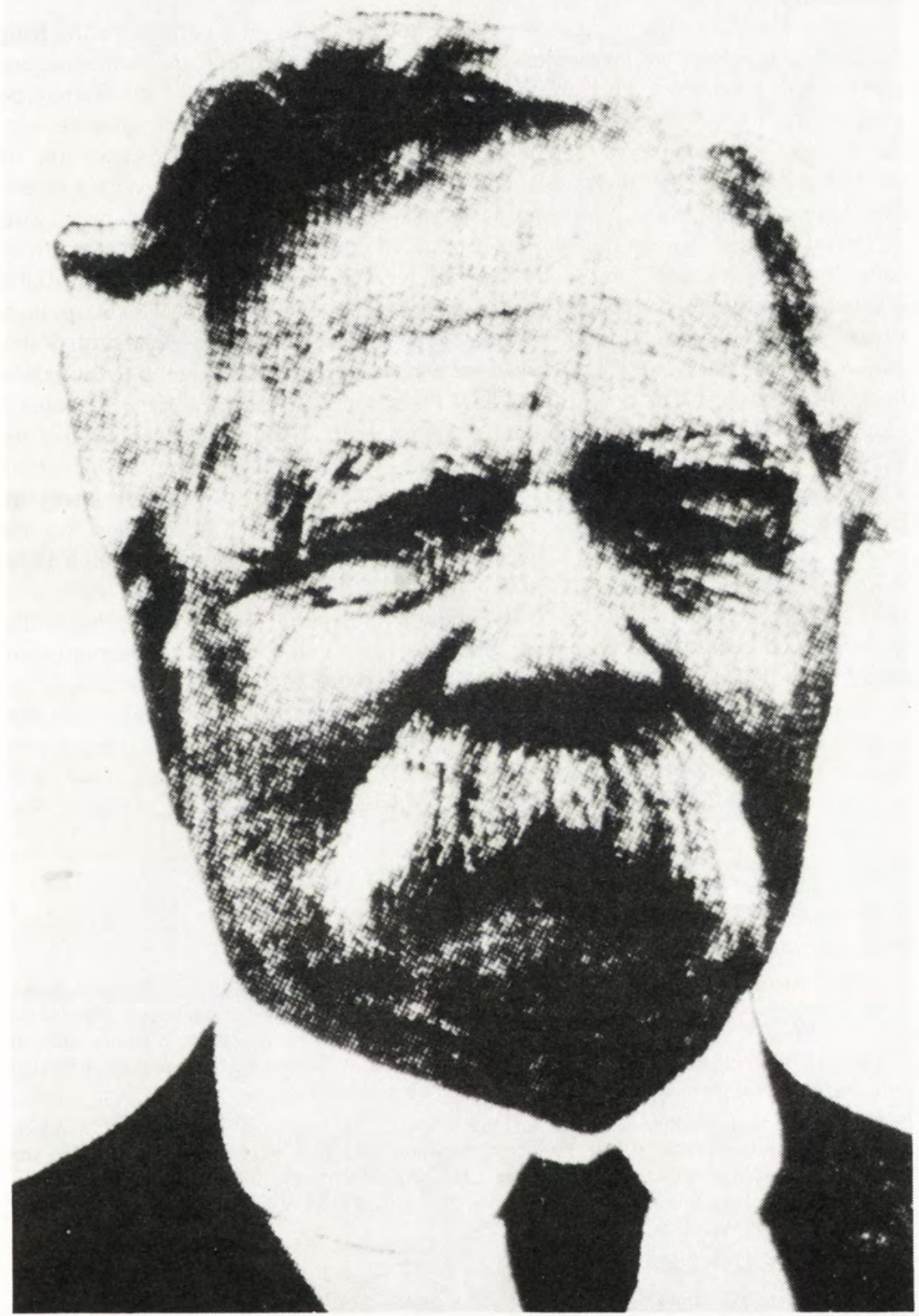

William Cooper at the time of the preparation of the petition to the King (The Ladder, 1(5), 1937). 
was designed to protest against 150 years of mistreatment and to draw attention to the plight of Aborigines at a time of rejoicing and celebration in the European community. ${ }^{13}$

During Cooper's early years in Melbourne the organising of a petition to the King calling for measures to prevent extinction, improved conditions and parliamentary representation occupied much of his time. Together with members of the Melbourne community Cooper believed that the Crown had reserved certain powers over Aborigines, in evidence of which he cited a South Australian proclamation of 28 December 1836 by Governor Hindmarsh and a similar document relating to the Port Phillip district as the Aborigines' Magna Carta. ${ }^{14}$ In the period $1933-5$ over 1,800 Aborigines signed the petition despite fear of victimisation, ${ }^{15}$ and obstruction from some government authorities. South Australia, New South Wales and Western Australia granted permission to circulate the petition, although only after the West Australian Chief Protector launched inquiries into Cooper's character and the New South Wales authorities stipulated that 'nothing is done to cause disaffection' amongst Aborigines living on reserves. ${ }^{16}$ The Queensland Chief Protector, J.W. Bleakley, denied Cooper's request 'by direction of the Honourable the Minister'. When Cooper replied that he had received favourable answers from some states Bleakley inquired of other authorities, including the Minister for the Interior who replied two months later that the Commonwealth had decided against assisting Cooper. ${ }^{17}$ The Minister for the Interior (with responsibility over the Northern Territory) had decided in March 1934 that the administration should not be associated with the collection of signatures after he was advised by Dr C.E. Cook, Chief Protector of the Territory, that while 'it might be considered reasonable that I afford aboriginals an opportunity of submitting their petition', the vast majority of Aborigines were incapable of understanding the "significance of appending their names . . . or comprehending the tenor and purpose of the petition itself'. ${ }^{18}$ Despite such obstruction 900 signatures were obtained (surreptitiously?) on Palm Island, a further 12 came from other parts of Queensland and 9 from Goulburn Island Mission in the Northern Territory; 500

13 Horner 1974:48, chapter 5 .

14 Browne, 'Australian Aborigines' League' (AA, CRS, A431, 45/1591).

15 A. Burdeu to Rev. W. Morley, 19 June 1936, Association for the Protection of Native Races, Records: 'Mr. Cooper has just called to see me . . . [About 2,000 names have been collected on the petition]. These are from all over Australia and ought to be far greater in number but for the fact that certain natives were afraid to sign, notwithstanding that the managers assured them that it was quite allowable. They felt there was a catch in it ...'

16 W. Cooper to J. Perkins (Minister for the Interior), 21 November 1933 (AA, CRS A431, 45/1591); A.O. Neville (Chief Protector, Western Australia) to Secretary, Board for the Protection of Aborigines, 27 September 1933 (AA Melbourne, CRS B337, 187); Minutes, Aborigines Welfare Board, New South Wales, 13 April 1934 (N.S.W. State Archives, Aboriginal Welfare Board, microfilm 2792).

17 AA, CRS A431, 45/1/1591.

18 C.E. Cook to His Honour, The Administrator of the Northern Territory, 19 February 1934 (AA, CRS A431, 45/1/1591). 
were obtained in Westem Australia, 350 in South Australia, and less than 100 each in New South Wales and Victoria. ${ }^{19}$

The petition's circulation seems to have been completed early in $1935^{20}$ yet it was not presented to the Prime Minister for transmission to the King until September 1937. Perhaps it was regarded as a last resort, to be used when all other avenues had been exhausted. The deputation of January 1935 had already made the request for parliamentary representation only to have it rejected by cabinet. ${ }^{21}$ In November 1937 Cooper told the journalist Clive Turnbull that if we cannot get full justice in Australia, we must ask the King. Some tell us that the King has no power now in these things, but we shall try anyway'.22 The petition, however, failed to reach its destination; instead of transmitting it the government, after examining its merits, decided at the cabinet meeting of 7 February 1938 (shortly after the Day of Mouming and the Aboriginal deputation) that 'no action be taken'. ${ }^{23}$ Cabinet minutes provide no indication of the actual discussion but public service records and the written submission to cabinet indicate the context in which it was considered. The inability of a large number of the petitioners to sign their names and the failure to indicate their breed ('there is no indication ... as to whether the petitioners are full-blood aboriginals or persons of part aboriginal blood') ${ }^{24}$ aroused comment within the Department of the Interior. It was felt that 'very few aboriginals have the ability to exercise a vote'.25 The Secretary of the Interior, J.A. Carrodus, wrote on 10 November 1937 to Professor J.B. Cleland, a pathologist with a special interest in Australian Aborigines, that "with your intimate knowledge of natives you will realise how difficult it would be for His Majesty to give effect to the requests of the petitioners'. On an earlier occasion Carrodus had argued that the education of 'full-blood' children was, 'in the main, ... a waste of time' and that comparison with New Zealand was inappropriate as 'the Maori is a much more highly developed native than the aboriginal'.26 The SolicitorGeneral, when asked for an Opinion on the Commonwealth's power to grant representation to Aborigines (there was no consideration of the right to interfere with the passage of a petition to the King), advised that while there was no power to grant representation in the states, there was power under section 122 of the constitution (dealing with territories) to grant representation to Aborigines of the

19 AA, CRS A431, 45/1/1591.

20 In a letter dated 8 April 1935 (W. Cooper to T. Patterson, Minister for the Interior) Cooper writes of having received 2000 signatures (AA, CRS A431, 45/1/1591).

21 Commonwealth Parliamentary Debates, 147 (26 September 1935):278.

22 Northern Standard [Darwin], 4 January 1938, reprinting article from the Brisbane Courier-Mail.

23 Extract from cabinet minutes 7 February 1938 (AA, CRS A461, A 300/1, Part III).

24 J.A. Carrodus (Secretary, Interior) to Secretary, Prime Minister's Department, 30 September 1937 (AA, CRS A461, A 300/1, Part III).

25 J. Barranger, Department of the Interior Memorandum 36/3037, 22 September 1937 (AA, CRS A431, 45/1591).

26 AA, CRS A431, 45/1591; Department of the Interior Memorandum 32/2470, 4 April 1935 (AA, CRS A1, 35/3951). 
Northern Territory.27 This may have been unwelcome advice and there is to indication, besides some press speculation, ${ }^{28}$ that the possibility received seriols consideration. McEwen, Minister for the Interior, argued in his cabinet submission that the Aborigines of the Territory were already 'virtually' represented in the parliament in the person of the responsible minister (that is, himself). As for the other aspects of the petition dealing with extinction and the provision of better treatment, the variols authorities were already 'doing everything possible': 'all governmental authorities $n$ Australia fully appreciated their responsibility in connection with the welfare of aboriginals generally'.29

Cooper and other Aboriginals had received a hearing, and some sympathy, from senior members of the Commonwealth government. Some publicity was gained, bit there was little if anything in the way of concrete results. The Aboriginal voice was but one amongst many and not one that was accorded any special notice. A seriors hearing, and hence the possibility of influence, was restricted to Europeans with in immediate interest in government policy, notably in the pastoral industry, academe, and the major pressure groups.

References to Cooper's activities in the 1930s are to be found in several work: Mavis Thorpe Clark's Pastor Doug, Jack Horner's Vote Ferguson for Aborigiral Freedom, and Diane Barwick's entry on Cooper in the Australian Dictionary of Biography. Unpublished material, particularly from the files of the Department of the Interior and of the Prime Minister, held in the Australian Archives, Canberra, provides the basis for a fuller account. In addition to newspaper cuttings these files contain a report on the Australian Aborigines League by the Commonwealth Investigation Branch (prepared following receipt of the petition), a copy of the Solicitor-General's Opinion and some 35 letters, 33 of which purport to bear Cooper's signature. Of these 33 letters 26 are originals ( 9 handwritten) and 7 are typed copies prepared within the public service. It is most unlikely that all were written by Cooper as there are significant variations in the syntax as well as in the handwriting, and a number of the early letters bear signatures at variance with Cooper's. On the following pages a selection from this unpublished material is reproduced. It was chosen with the primary objective of focusing on the petition to the King but also includes material indicating the broader concerns of Cooper and his co-workers. It includes the petition, nine letters from Cooper, an extract from the McEwen cabinet submission and the league's submission to the official's conference of April 1937.30

27 Attorney General's Department, Opinion 6 of 1938, 'Representation of Aboriginals in Commonwealth Parliament ...' (AA, CRS A461, A 300/1, Part III).

28 Sydney Morning Herald, 18 January 1938:11.

29 J. McEwen, (Cabinet submission) 'Australian Aborigines' League - Petition to His Majesty the King', 1 February 1938 (AA, CRS A461, A 300/1, Part III).

30 There are three major files relating to the league. Of the nine letters reproduced the first, second and third are taken from the Department of the Interior file CRS A431, 45/1591, the fourth from the Interior file topnumbered into Immigration, CRS A659 42/1/8104, and the remaining five (together with the McEwen submission) from the Prime Minister's Depariment file CRS, A461, A 300/1, Part III. 
DOCUMENTS

1.

Of the Aboriginal inhabitants of Australia to His Majesty, King George VI, by the Grace of God, of Great Britain, Ireland, and British Dominions beyond the seas, King; Defender of the Faith; Emperor of India.

\section{TO THE KING'S MOST EXCELLENT MAJESTY, IN COUNCIL}

THE HUMBLE PETITION of the undersigned Aboriginal inhabitants of the Continent of Australia respectfully sheweth:-

THAT WHEREAS it was not only a moral duty, but a strict injunction, included in the commission issued to those who came to people Australia, that the original inhabitants and their heirs and successors should be adequately cared for;

AND WHEREAS the terms of the commission have not been adhered to in that -

(a) Our lands have been expropriated by Your Majesty's Governments, and

(b) Legal status is denied to us by Your Majesty's Governments;

$A N D$ WHEREAS all petitions made on our behalf to Your Majesty's Governments have failed. YOUR PETITIONERS humbly pray that Your Majesty will intervene on our behalf, and, through the instrument of Your Majesty's Governments in the Commonwealth of Australia will prevent the extinction of the Aboriginal race and give better conditions for all, granting us the power to propose a member of Parliament, of our own blood or white men known to have studied our needs and to be in sympathy with our race, to represent us in the Federal Parliament.

AND YOUR PETITIONERS WILL EVER PRAY

[Signatures of Petitioners.]

[Addresses.]

2. W. Cooper, 120 Ballarat Road, Footscray, to Honourable Mr. Lyons, Prime Minister of Australia, 23 October 1933.

On behalf of my people I have the honour to most humbly approach you seeking your permission to send to, and have signed by the Aboriginal Population under your charge, the undermentioned petition, a copy of which is to be forwarded to His Majesty King George V of England, asking on our behalf to do his utmost in taking suitable steps in preventing the extinction of the Aboriginal Race.

I. Obtaining better conditions for all.

II. Obtaining power to propose a Member of Parliament to be chosen by my people to represent them in the Federal Parliament.

Trusting that my humble request will receive every consideration. I have the Honour to be, $\ldots{ }^{31}$

3. W. Cooper, 120 Ballarat Road, Footscray, to Mr. N. Makin [Labor M.H.R. for Hindmarsh, S.A.] , 19 March 1934.

Why can't Mr Bleakley give me something definite, as regards my petitioning my own people for signatures in Queensland, as each of the other States have done, it is just upon six months since I first applied, and the enquiries of the attitude of the other States are still being put forward

31 Similar letters seem to have been sent to the authorities in the various states. Undated (September 1933?) letters to the Victorian Board for the Protection of Aborigines and the Chief Protector of Aborigines, Western Australia, are located at AA Melbourne, CRS B337, 187. 
as the reason, surely it does not take all that time to get an answer, other matters of less importance get more business action than this has, the whole matter is being held up, as my people do not want to do anything against the Board of Protection, yet are willing to sign so long as it will not offend.

If something decisive is not arrived at very soon, greater publicity will be given to the unnecessary delay meted out by the Board, their duty is to help our race in a reasonable manner as we are Subjects of the Realm.

In your reply dated 4 Dec 33 you suggest that if there is any objection raised to apply to yourself or some other Member, will you please accept my appeal and try to help me, thanking you in anticipation. ${ }^{32}$

\section{W. Cooper, 27 Federal St., Footscray, to Mr Paterson, Minister For Interior,} Signed W. Cooper, 'On behalf real Australian Native Association'. 8 April 1935.

On behalf of the Aborigines population of Australia from whom I have received 2000 signatures, from all parts of Australia authorising me to plead for justice; And noticing the continual reports in daily presses of ill treatment of Aborigines, reports of a similar nature have been coming from different parts of Australia. Fifty years to my knowledge. in my travels through Queensland, South Aust, N,S, Wales and Victoria, have noticed large tribes of Aborigines, and to my estimation appeared hundreds of thousands. Turning to the general liberty of early history estimates millions of Aborigines, and it is publicly known the numbers reduced from Millions, to 70,000 Aborigines all told. Sir, we humbly pray that you will intervene on our behalf through instrument of the government in the Commonwealth of Australia, to prevent the gold seekers, settlers, and others, from further ill treatment to Aborigines. Trusting a favourable consideration will be given to our requests, and your petitioners will ever pray.

\section{W. Cooper, 27 Federal St., Footscray, to [J. Lyons] The Rt. Hon. the Prime Minister, 22 July 1936. Signed W. Cooper, Hon. Secretary Australian Aborigines' League.}

The aborigines are looking forward with deep concern to the forthcoming conference of Premiers in Adelaide next month as they feel that their destinies are somewhat involved.

You have undertaken to bring the matter of aboriginal control and policy to the conference and we do plead that no circumstance be permitted to shelve or delay the matter.

We do plead for one controlling authority, the Commonwealth and request that all aboriginal interests be absolutely federalised. This will enable a continuous common policy of uplift, which we trust will contain provision for the exploitation of all natives' reserves by the natives, under able leadership, and for the natives. We submit an aim, which is practicable, and that should be the ultimate self liquidation of the whole problem of uplift. So far from the aboriginal continuing to be a charge on the community, he can be made under sound and capable direction to be an asset to the community. This is a long vision no doubt.

We plead for this, but if the Premiers are not willing to lose a responsibility they do not wish to retain we plead for a common policy under Commonwealth control or influence with a subsidising of the States on the aboriginal per capita basis. We have no hope where the States with large aboriginal populations cannot adequately finance their obligations and the States with small aboriginal populations, or none, as in the case of Tasmania, should not be freed from responsibility.

We would request that the request of this League for parliamentary representation be considered. If the whole control is federalised this should be readily concedable, but if the States

32 Makin wrote to the Minister for the Interior, Hon. J. Perkins, on Cooper's behalf on 29 March 1934. 


\section{WILLIAM COOPER AND THE 1937 PETITION}

retain control, we submit that such representation should be accorded to our people in the States' legislature, at any rate where the aboriginal populations are numerous.

Trusting that you will bring these requests to the notice of the Premiers, $\ldots{ }^{33}$

6. W. Cooper, 27 Federal St., Footscray, to J. Lyons, The Rt. Hon. the Prime Minister, 16 January 1937. Typed on league stationery, signed W. Cooper, Hon. Secretary.

I take the liberty of enclosing for your information a copy of an agenda of suggestions for the forthcoming meeting of Chief Protectors of Aborigines and other administrative officers.

We looked forward to the late Premiers' conference as the means of our emancipation. Now that the consideration has been passed on to the administrative officers for consideration and recommendation we are hoping that our proposals will be kept in mind.

I will forward a copy also to the Minister for the Interior and one to each Minister of the Crown concerned and the Chief Protectors.

Our case is desperate in different parts and only by subsidy can the States hope to improve our lot. They have, in some cases, the will to do so but lack the financial capacity.

\section{AUSTRALIAN ABORIGINES' LEAGUE}

AGENDA of proposals submitted by the Australian Aborigines' League for the consideration of the Conference of Chief Protectors and others.

1. That all aboriginal interests be federalised with a Federal Ministry for Aborigines. Failing this

2. That there be coordination between State Departments with a view to a common policy for the whole of the Commonwealth.

3. That a National Policy be formulated for the uniform and systematic uplift of the aboriginal population throughout Australia.

4. That the cost of administering the aboriginal policy be a charge, on a per capita basis, against the whole of Australia, thus enabling the States with a large white population and a comparatively small aboriginal population sharing the cost with $S$ tates with a large aboriginal population and a relatively small white population.

5. That all approved aboriginals of full or part aboriginal blood be allowed to adopt an independent status and that, in that condition, they be not subject to any disabilities in law, political, civil or economic, as aboriginals. That such aboriginals be entitled to all the rights of white persons as maternity bonus, old age and invalid pensions, sustenance (work for dole and relief work) while unemployed, etc.

6. That all aboriginals of full or part blood have the right to live in reserves set apart for aboriginals. That expulsion from reserves for breach of discipline or other cause shall not be permitted without open enquiry at which the charged aboriginal shall be allowed assistance for his defence, legal assistance if desired. Any aboriginal discharged from an aboriginal station shall be treated in the matter of sustenance as an aboriginal electing to live privately, if unemployed.

7. That no advantage shall accrue to any class of aboriginal over another, i.e., that full bloods with those of any degree of mixed blood shall have equality of treatment and opportunity.

33 The Premier's Conference decided that 'owing to the fact that aboriginals in the different States are in various stages of evolution, and that each State presents its own problems, it would be undesirable and impracticable to have centralised control of the whole of the aboriginals in Australia'. A need was recognised, however, for periodical conferences between bodies 'controlling aboriginals' to discuss 'methods of control' and the general question of the natives' welfare. 


\section{ABORIGINAL HISTORY 1983 7:1}

8. That the aboriginal population shall be grouped into classes determined by the stage of their progress and that the policy of the Administration shall be the progressive elevation from one class to an higher one till the whole race is fully civilised and cultured. These groups shall be:-

(a) Myall Aboriginals.

(b) Partly civilised and detribalised aboriginals.

(c) Civilised aboriginals.

9. That education be provided for all aboriginal children, designed to permit all who are capable of qualifying, to attain to the highest standard. As may be justified, secondary schools for aboriginal children shall be provided. Where this is not possible, aboriginal children and young people shall have the right to attend secondary schools set apart for white children. The education of all aboriginal children shall be academic and vocational.

10. That all aboriginals be encouraged to work in the industry of civilisation; that they have the right to work and that all able-bodied unemployed, aged, sick and infirm aboriginals shall have the assurance of full sustenance, the third group of aboriginals to be treated for sustenance as whites in parallel circumstances are treated, viz., payment of dole, old age or invalid pension, or as the case may be.

11. Suitable areas of land shall be set apart for the increasing aboriginal population. These should be large enough to permit of the development of full self-reliance, all community services being rendered, where possible, by aborigines. All reserves should be fully developed by the most up-to-date methods under expert direction. Young aboriginals should be encouraged to settle in these reservations but there should not be any compulsion on aged persons to leave areas that they have become attached to. Aboriginal reserves to be inalienable and whites not to be allowed thereon only by permission.

12. That trained and qualified aboriginals be allowed to settle on lands and to work them for their own profit, the ultimate design of all training in settlements being with this independency in view.

13. All offences by aboriginals to be subject to punishment only to the extent that white persons are punishable, due regard being paid to the implications of aboriginal law or psychology. Offences by whites against aboriginals to be punishable on the same basis as offences by whites against whites and offences by aboriginals to be punishable only to the same degree as in the case of offences by whites against whites. In other words there shall be full equality of whites and aboriginals before the law.

7. W. Cooper, 43 Mackay St., Seddon, to Mr. Lyons, the Rt. Hon. The Prime Minister, 26 October 1937. Typed on Australian Aborigines' League stationery, featuring league's motto: 'A fair deal for the dark race'. Signed W. Cooper, Hon. Sec.

Thank you for your acknowledgement of our petition to His Majesty and the promise of fullest sympathy and consideration. We know you will give this and we do thank you for the definite interest you have in our cause. I would, however, offer the following comment in respect of the pen-ultimate clause of your letter of 17 th inst. ${ }^{34}$ and would request that these comments be in mind in the consideration promised.

His Majesty is King of Australia, and, on this account, the State control of aborigines should not prevent consideration being given on a national basis. I am not, therefore, able to appreciate

34 F. Strahan, Secretary, Prime Minister's Department, to W. Cooper, 17 October 1937. This letter stated that 'fullest consideration will be given at the earliest possible date to the matters referred to in your petition'. It continued in the penultimate paragraph: 'As you are aware, Commonwealth control of aboriginals is limited to those living in the Northern Territory aboriginals in the States coming under the jurisdiction of the various State Governments. The Governments of the Commonwealth and in the States are doing every thing possible to prevent the extinction of the aboriginal race and to provide better conditions for aboriginals generally.

(cont.) 


\section{WILLIAM COOPER AND THE 1937 PETITION}

the reference to the natives of the Territory in particular and to the jurisdiction of the State Governments. We do trust that the division of the administration over State Legislatures, which is always to our detriment, will not retard our relief. With all respect, since our petition is to the King of Australia, it should not be possible for divided control hurting us in this instance.

Respecting the conference of Chief Protectors, from which we scarcely expected relief, and which, so far as we can see only resulted in one decision which was not previously operative, and that the recognition of the wives of aboriginals married according to Tribal Law being recognized as legal wives and thus not being compellable witnesses. From our point of view the conference was only a waste of time. We did expect a Magna Carta from the Premiers' Conference but from the conference of Chief Protectors we only got the confirmation of our humiliation. Frankly, we are alarmed at the intention to seek advice from countries where Negro populations constitute the dark problem for we, notwithstanding all our indignity, are allowed to walk on footpaths, ride in public vehicles and trains and put up in many hotels where white men are residing. ${ }^{35}$ To add to our sorrows the humiliation of our dark brethren overseas in the curfew and the pass system would be degradation indeed. In due course we will present you with our comment on the published minutes of the conference but meantime we are in protest against the whole result. We do claim that the forwarding of our petition be not clouded with the State aspect of the atmosphere of the Chief Protectors' conference.

Respecting our claim for parliamentary representation, we very definitely submit that the Maori population is approximately the same as our people, with any advantage to us. In an area the size of Victoria they have four members and a Ministry for Native affairs, which has had a native minister. We are persisting in our claim for one who can speak for us in Parliament, influencing legislation on our behalf and safeguarding us from administrational officers, who with notable exceptions, interpret their responsibilities to the aborigines in much the same way as a gaol governor does his criminal population. Our desire is a change of heart in the electorate, reflected in Parliament and leading to a policy which will be different from that administered by our gaolers. So far from divided control being allowed to retard our securing representation, we feel that our member should have the right to sit in every legislature, and any constitutional difficulty could be overcome by legislation. If our member were a member of the Senate, perhaps, as this is a States' Rights House, any difficulty might be more easily overcome.

Hoping to hear shortly of the granting of our requests, ...

The discussions that took place at the recent Conference of Commonwealth and State officers charged with the protection of aboriginals indicated that all Governmental authorities in Australia fully appreciate their responsibility in this connection.'

35 The initial conference of Commonwealth and State Aboriginal authorities was held in Canberra, 21 to 23 August 1937. It was resolved, inter alia, that 'Realizing ... [ [the need for] enlightened guidance . . . this Conference is of opinion that the Commonwealth should take steps as seem desirable to obtain full information upon racial problems in America and South Africa for submission to a further conference of Chief Protectors to be held within two years.' No further conference was held but approaches were made to government authorities leading to an exchange of official publications with the Office of Indian Affairs, United States Department of the Interior, and the despatch of an eight page summary of government policy addressed to Prime Minister Lyons from (General) J.M.R. Hertzog, Minister for External Affairs, Union of South Africa. (AA, CRS A461, A 300/1 Part III). 


\section{AUSTRALIAN ABORIGINES LEAGUE - PETITION TO HIS MAJESTY THE KING}

[The first half of the submission notes the content of the petition, provides details on the petitioners - total, geographical distribution - and gives brief particulars on the Aborigines' League.]

5. The Department can speak with authority only in regard to the aboriginals of the Northern Territory, because Commonweal th control of aboriginals is limited to that Territory, the aboriginals in the States coming under the jurisdiction of the various State Governments.

6. With regard to the prevention of the extinction of the race and the provision of better conditions for aboriginals generally, the Commonweal th Government and the various State Governments interested are doing every thing possible. It was evident from the discussions that took place at the Conference of Commonwealth and State Officers charged with the protection of aboriginals held at Canberra in April, 1937, that all governmental authorities in Australia fully appreciate their responsibility in connection with the welfare of aboriginals generally.

7. The question of whether aboriginals could be given representation in the Commonwealth Parliament has been considered by the Solicitor-General, copy of whose Opinion is attached. It will be seen that -

(a) the Commonwealth Parliament has no authority to pass legislation to give representation in Parliament to aboriginals qua aboriginals who live in the States of the Commonwealth; and

(b) Section 122 of the Commonwealth Constitution would appear to be a grant of sufficient authority to Parliament to provide that aboriginals in the Northern Territory may elect an aboriginal member for that Territory to represent them as such; but these elective powers could only be conferred on the aboriginals living in Territories of the Commonwealth and not in Australia as a whole.

8. As Minister for the Interior, I am virtually a representative of the aboriginals of the Northern Territory. I am responsible for carrying out the Government's policy in the Northern Territory and for bringing forward new legislation in the form of Ordinances and Regulations which must be submitted to Parliament.

9. It is not seen that any good purpose would be gained by submitting the petition to His Majesty the King, and it is recommended that no action be taken.

(J. McEwen)

Minister for the Interior. $1 / 12 / 1938$

9. W. Cooper, 73 Southampton St., Footscray, to [J. Lyons] The Rt. Hon. The Prime Minister, 23 May 1938. Typed on league stationery, signed W. Cooper, Hon. Secretary.

Re our petition to the King for a representative in Parliament in respect of which there was considerable press publicity some months ago, which we believed to be inspired.

We are much concerned with the fact that there is now no further comment and no word from you in the matter. Would you please tell us how it now stands. ${ }^{36}$

36 A letter which seems to have been sent on 2 March 1938 advising of the Cabinet decision does not seem to have reached the league. A letter from the Secretary of the Prime Minister's Department of 9 November 1938 refers to this earlier letter without indicating its precise contents (AA, CRS A1, 38/4793). 
There have been statements that the whole matter of Aboriginal Administration is being referred to another conference of Premiers but not having heard of this either we wonder if that has also been abandoned. We certainly were perturbed about two matters, one being in the minutes of the conference of Chief Protectors to the effect that advice was being sought in America and South Africa on the problem as there existing and the other was from your Department to the effect that the Commonwealth was seeking to induce the States in the way of initiating legislation similar to the iniquitous legislation recently enacted in Western Australia. In the matter of the first we trust that there will not be copying of the shocking treatment of the natives in either place. Here, if we have the money we are allowed to ride in trams and walk on footpaths and, in the civilised parts, white men will treat colored women as women. Cannot our legislators evolve a scheme for Australia and cannot that scheme be that every civilised man and woman, full blood or half caste shall have full equality in law. Why should we be legislatively considered as we were when the white man came to our shores. Is there no time that we can look forward to when we shall be fully human in the eyes of white legislation?

The second matter, the suggested legislation in all States on the lines of the Western Australian legislation. We feel quite definitely that the white community here would not stand for the degradation of the native here as he has been degraded in West Australia in the last months. There men who were educated and have been in the enjoyment of the franchise for quarter of a century are declared aboriginals. ${ }^{37}$ They may not now give their daughters in marriage without in every case receiving the personal consent of the Commissioner for Native Affairs. They may not go to Perth without a permit nor work for a white employer without securing a license at the price of $£ 1$ per year. For God's sake don't have us all pushed back to West Australian status but rather show that State that their retrospective legislation is foreign to Australian sentiment.

We fully trust you and your Government. We know we can look to you for justice but we are not so sure of the Administrative officers in the States who may be able, as in West Australia, to manipulate legislation to our detriment.

We are waiting most anxiously and will be glad of a word from you.

10. W. Cooper, 73 Southampton St., Footscray, to Hon. R.G. Menzies, M.P., Prime Minister Elect, 19 April 1939. Typed on league stationery, Signed W. Cooper, Hon. Secretary.

I am writing to you on the occasion of your selection of a cabinet to bring to your notice the great importance, from the point of view of my people, of the appointee to the Ministry for the Interior.

Mr. Lyons' government has the credit of being the one which has done more for aboriginal uplift, either in promise or fulfilment, than has any other Government. I am glad to say that I communicated to him the gratitude of my people at a time he could appreciate it. I know he did. Mr. Lyons has selected a sequence of Ministers for the Interior who have inspired confidence from the natives and the culmination has been found in the announced policy for aborigines. This has been good, mostly, and the parts we don't approve have been brought to notice in the hope that, when finally operative, the policy will make it possible for us to take our place as Australians.

A request such as the one I am to make would be deemed an impertinence from some people but it is a matter so fraught with moment to us that I feel we must mention the matter and I feel that you will accept the request in the spirit in which it is made. "Will you please select a minister for the Interior who will continue to maintain his administration with the desire to fully help the natives into full British Culture"?

37 The Western Australian Native Administration Act of 1936 extended the definition of Aborigines from 'persons of half-blood' and children of a 'half-caste woman deemed to be an aboriginal' to 'any persons of less than full-blood who is descended from the original inhabitants of Australia', with some exceptions. See Biskup 1973:170-1. 
Mr. Lyons has assured me that all his ministry shared his sympathy for my race. This includes yourself. I do trust that care for a suffering minority will ensure that kindliness of treatment that will not allow Australia's minority problem to be as undesirable as the European minorities of which we read so much in the press.

Will you kindly make yourself conversant with the petition to His Majesty, now being held in the Office of the Prime Minister. It may be that you will be able to recommend some of the requests there made.

11. W. Cooper, 73 Southampton St., Footscray, to Mr. Menzies, The Rt. Hon. The Prime Minister, 5 October 1939. Typed on league stationery, Signed W. Cooper, Hon. Secretary.

At a meeting of the League held yesterday concern was expressed at the delay in hearing the result of the petition to His Majesty, asking, inter alia, that representation in Parliament should be afforded to our race.

I would be glad of advice which I can pass on to our members.

\section{BIBLIOGRAPHY}

Aboriginal Welfare: Initial Conference of Commonwealth and State Aboriginal Authorities, Canberra, 1937?.

Association for the Protection of Native Races, Records, University Archives, University of Sydney. Australian Archives, Canberra:

Department of Immigration, 'Conference of Commonwealth and States', CRS A659, 42/1/8104.

Department of the Interior, 'Australian Aborigines' Amelioration Association. Re Aboriginal Affairs 1932-8', CRS A1, 38/12974.

'Welfare of Aboriginals in Northern Territory. Deputation to Minister 23 January 1935', CRS A 1, 35/3951.

'Assaults by Aborigines on white women. N.T.', CRS A1, 38/4793.

'Representation of Aborigines in Commonwealth Parliament', CRS A431, 45/1591.

'Victorian Aboriginal Group', CRS A431, 48/961.

Prime Minister's Department, 'Aboriginals - Policy ... . CRS A461, A300/1, Parts II and III.

Australian Archives, Melbourne:

Board for the Protection of Aborigines, Aborigines' case files, 'William Cooper', CRS B337, 187.

Barwick, Diane. 'Cooper, William', in Australian Dictionary of Biography, eds B. Nairn and G. Serle, vol. 8, pp. 107-8. Melbourne, 1981.

Biskup, Peter. Not Slaves, Not Citizens: The Aboriginal Problem in Western Australia 1898-1954. St Lucia, 1973.

Cato, Nancy. Mister Maloga: Daniel Matthews and his Maloga Mission, St Lucia, 1976.

Clark, Mavis T. Pastor Doug: The Story of Sir Douglas Nicholls, Aboriginal Leader. Adelaide, 1965. Horner, Jack. Vote Ferguson for Aboriginal Freedom: A Biography. Sydney, 1974.

Jackson, W.K. and G.A. Wood, 'The New Zealand Parliament and Maori Representation', Historical Studies, 11(43), 1964: 383-96.

New South Wales State Archives, Aboriginal Welfare Board, Minutes, microfilm 2792.

Patten, J. and W. Ferguson. Aborigines Claim Citizen Rights! A Statement of the Case for the Aborigines Progressive Association. Sydney, 1938. (Reproduced in Horner 1974: 192-198).

Pocock, J.G.A. (ed.). The Maori and New Zealand Politics. Auckland, 1965.

Stanner, W.E.H. and Diane Barwick, 'Not by eastern windows only: anthropological advice to Australian governments in 1938', Aboriginal History, 3(1), 1979: 37-61.

Victorian Public Records Office, Board for the Protection of Aborigines, Register of Inwards Correspondence, Series 10768. 